J. Product. \& Dev., 24(1): 153 - 164 (2019)

\title{
EFFICIENCY OF SOME ANTIBIOTICS APPLIED TO CONTROL AMERICAN FOULBROOD DISEASE INFECTING HONEY BEE COLONIES ,Apis mellifera L.
}

M. Abdel-Baset ${ }^{1}$; F. El-Santeel ${ }^{2}$; H. El-Sharkawy ${ }^{2}$ and A. Khattaby ${ }^{1}$,

1. Plant Protection Research Institute, A.R.C., Dokki, Giza-Egypt.

2. Department of Plant Production, Faculty of Technology \&Development,

Zagazig University, Egypt

ABSTRACT:

The present study was carried out during summer season of 2017 in a private apiary located in sefyta village at Sharkia Governorate to investigate the effect of three antibiotics applied in different methods to control the American foulbrood disease(AFB) caused by Paenibacillus larvae.

Obtained results cleared that the most potent antibiotic used to control AFB was tylosin which showed the highest efficiency when used in powdered sugar as it resulted in the highest reduction percentage in the numbers of infected cells, being insignificantly differed as compared to rifampcine in powdered sugar. On the other hand, the antibiotic oxytetracycline showed the least efficiency. Control colonies showed an increase in the number of infected cells.

Conclusively, Tylosin was the most effective antibiotic used in controlling American foulbrood disease when it used in the powdered sugar methods in decreasing the number of infected cells where the average number of infected cell decreased from 183.33 before treatment to 10.00 after the $4^{\text {th }}$ treatment and in the reduction percentage, where its reduction percentage was $96.47 \%$.

Keywords: American foulbrood, Paenibacillus larvae, Honey bee , Apis mellifera,Control, Antibiotics.

\section{INTRODUCTION}

American foulbrood is considered one of the most consequential and severe disease affecting honey bees, Apis mellifera and one of the few diseases that causes complete collapse of the infected colonies (Alippi et al. 2007) . The causative agent of American foulbrood is the rod-shaped $(2.5-5 \mu \mathrm{m}$ by $0.5-0.8$ $\mu \mathrm{m}$ ), gram-positive, spore-forming bacterium, Paenibacillus larvae (Alippi et al. 
2002). Larvae are most susceptible to american foulbrood between 12-36 hours after hatching, with infection occurring through the ingestion of Paenibacillus larvae spores (Genersch et al. 2005). The spores of $p$. larvae germinate and proliferate in the midgut, invading the larval tissue where it continues to proliferate and produce billions of spores per infected larva. (Yue et al. 2008) .The spores are very long-lived and resistant to heat and chemical agents. only the spores are capable of inducing the disease (OIE. 2013). The infected larva eventually dies and was degraded by $P$. larvae to a brownish, semi-fluid gluelike colloid usually known as a "ropy mass"-the primary clinical symptom for diagnosis of AFB. Brood combs of infected colonies show a patchy brood pattern, and the capping of cells containing diseased honeybee larvae appear darkened and sunken with a greasy look and abnormal perforations. The semifluid glue-like colloid eventually dries down to a hard scale tightly adhering to the lower cell wall (Forsgren et al. 2018).

Chemicals and antibiotics have been used in controlling AFB disease but, there is no effective long-term control for AFB. Applying antibiotics is the main control method in many countries (Ryba et al. 2012). There are 4 techniques for applying antibiotics; dusting, bulk feeding, extender patties and paper packs. (Morse and Shimanuki 1990). OTC have been used more frequently in many countries to control AFB ( Alippi et al. 2007). Tylosin, a macrolide antibiotic, has been used globally in beekeeping. Its efficacy was proven by different authors in field and laboratory such as Peng et al. 1996, Bastos et al. 2008 and Reynaldi et al. 2009. Rifampicin has good perspectives for treatment of bee bacterial diseases after examining sensitivity of $25 P$. larvae strains against different antibiotics (Gurgulova et al. 2003).

Therefore, the aim of this study to evaluate of some antibiotics applied to control American foulbrood disease infecting honey bee colonies, Apis mellifera $\mathrm{L}$.

\section{MATERIALS AND METHODS}

\section{Experimental honey bee colonies}

The present study was conducted in a private apiary located at Sefyta village, Sharkia governorate using 36 healthy colonies, nearly equal in strength. The test colonies were consisted of 5 combs covered with bees ( 3 sealed and un sealed brood combs and 2 combs of honey and pollen). Hived in a standard Langstroth hive body. The test colonies were neither manifested any apparent symptoms of AFB, nor received any antibiotics 6 months later. The colonies 
were re-queened with new Carniolan hybrid sisters queens obtained from Department Apic., Plant Protect. Research Inst., ARC.

\section{Artificial inoculation}

The experimental colonies were artificially infected with AFB disease using a spores suspension, prepared by mixing 100 cells of actively diseased brood (dried larval remains) collected from symptomatic colonies in sucrose solution $(1: 10 \mathrm{w} / \mathrm{v})$.

The artificial infection was established according to Evans and Pettis (2005) method by spraying immature bees (eggs, , and first-and second-instar larvae) with suspension of $P$. larvae. spores Colony inoculation was done twice at weekly intervals to make sure that all colonies were heavily infected (approximately 100 diseased cells /colony which considered a sever degree).

\section{The test antibiotics}

1- Tylosin tartrate-water soluble powder- for veterinary use -pack of 100 grams each $100 \mathrm{mg}$ contains $100 \mathrm{gm}$ of tylosin tartrate (eq.to $92.4 \mathrm{~g}$ base) obtained from El Nasr pharmaceutical chemical co., Abu Zaabal ,Egypt, using (total dose range from $600-800 \mathrm{mg}$, divided in to 3 or 4 doses weekly intervals with $200 \mathrm{mg}$ /hive /week ( Mutinelli , 2003 ; Elzen et al. 2002).

2- Oxytetracycline (OTC) (water soluble powder - for veterinary use)

Using the recommended dose found effective in a previous study (Chen et al. 2001) Using $200 \mathrm{mg} /$ hive / week for 3 weeks.

3- Rifampcine: using the recommended dose mentioned by Kochansky et al. (2001) 60mg /hive /week .

The antibiotics were applied using three methods of application (powder sugar, candy or patty, syrup) according to Morse and Shimanuki (1990).

\section{Experimental design}

The experimental colonies (36 colonies) were divided into four groups (3 treated with the antibiotics and one as control) in the complete randomized design, colonies of each group were sub divided into 3 subgroups of 3 colonies each to achieve the three methods of application of each antibiotic. The antibiotics treatments were applies once weekly for 4 weeks.

\section{Statistical Analysis:}

The results obtained were analyzed by ANOVA test using a computer program (Statistix) Heisey and Nimis (1985) to determine Duncan s multiple 
range test and the least significant difference (LSD 5\%) for the two experimental factors (antibiotics \& application methods ) and the interaction between the two factors.

\section{Calculating the reduction percentage:}

It was calculated using the formula of Henderson and Tilton (1955)

$$
\mathrm{R} \%=1-\left(\frac{n \text { in treatment after }}{n \text { in treatment before }} \times \frac{n \text { in control before }}{n \text { in control after }}\right) \times 100
$$

Where:

n: No. of infected cells

\section{RESULTS AND DISCUSSION}

The present study was performed in a private apiary at Sharkia Governorate during summer season of 2017 to evaluate the efficiency of tylosin, oxytetracycline and rifampicin, applied in powdered sugar, syrup and candy, in controlling the infection of AFB in honeybee colonies. Obtained data are as follow:

\section{1-Number of infected brood cells :}

Data presented in Table 1 and Fig. 1 clear that the number of infected brood cells in the test colonies, before any treatment ranged between 167.33-184.00 cells / colony without any significant differences. The number of AFB infected brood cells after the first $, 2^{\text {nd }}, 3^{\text {rd }}$ and $4^{\text {th }}$ treatments with tylosin were 147.55 , $122.89,68.44$ and 21.66 cells /colony respectively compared to 180.99 cells/colony before treatment . The corresponding numbers for oxytetracycline recorded $162.49,144.44,121.13$ and 92.44 cells/ colony compared to 177.67 cells/ colony pre-treatment . As for rifampicin the respective numbers were $145.33,97.22,57.77$ and 23.11 cells /colony after the four treatments compared to 173.66 cells /colony before treatment .On the other hand, control colonies manifested (suffered) increasing infected brood cells by time, recording 172.33 before , 181.78 , 201.43, 220.05 and 240.70 infected cell/ colony .Corresponding the pre and post treatments of the treated colonies.

It is clear that tylosin caused the highest effect followed closely by rifampicin, whereas oxytetracycline caused the least effect .However, the three test antibiotics reduced the number of infected brood cells as compared to control. 
Table (1): Effect of tylosin, rifampicin and oxytetracycline applied to AFB infected colonies in powdered sugar, sucrose syrup and candy on development of AFB infection after 4 treatments (applications)

\begin{tabular}{|c|c|c|c|c|c|c|c|}
\hline \multicolumn{2}{|l|}{ Treatment } & \multirow{2}{*}{\multicolumn{5}{|c|}{$\begin{array}{l}\text { Mean No. of infected brood cells } \\
\text { after the indicated treatments . }\end{array}$}} & \multirow[b]{3}{*}{$\mathbf{R} \%$ * } \\
\hline \multirow[b]{2}{*}{ Antibiotic } & \multirow[b]{2}{*}{$\begin{array}{l}\text { Application } \\
\text { method }\end{array}$} & & & & & & \\
\hline & & $\begin{array}{c}\text { Pre- } \\
\text { Treat. }\end{array}$ & $\begin{array}{l}\text { Post1 } \\
\text { Treat. }\end{array}$ & $\begin{array}{c}\text { Post } 2^{\text {nd }} \\
\text { Treat. }\end{array}$ & $\begin{array}{c}\text { Post } 3^{\text {rd }} \\
\text { Treat. } \\
\end{array}$ & $\begin{array}{l}\text { Post }^{\text {th }} \\
\text { Treat. }\end{array}$ & \\
\hline \multirow{4}{*}{ Tylosin } & $\begin{array}{l}\text { Powdered } \\
\text { sugar }\end{array}$ & $183.3^{\mathrm{a}}$ & $124.67^{b}$ & $91.67^{\mathrm{d}}$ & $64.33^{\mathrm{c}}$ & $10.00^{\mathrm{c}}$ & 96.49 \\
\hline & Syrup & $175.67^{\mathrm{a}}$ & $163.33^{\mathrm{ab}}$ & $141.0^{\mathrm{bc}}$ & $74.00^{c}$ & $33.00^{\mathrm{c}}$ & 86.70 \\
\hline & Candy & $184.00^{\mathrm{a}}$ & $154.67^{\mathrm{ab}}$ & $136.0^{\mathrm{bc}}$ & $67.00^{c}$ & $22.00^{\mathrm{c}}$ & 90.72 \\
\hline & Mean & 180.99 & 147.55 & 122.89 & 68.44 & 21.66 & 91.43 \\
\hline \multirow{4}{*}{ OTC } & $\begin{array}{l}\text { Powdered } \\
\text { sugar }\end{array}$ & $174.00^{\mathrm{a}}$ & $163.33^{\mathrm{ab}}$ & $145.67^{\mathrm{b}}$ & $125.03^{b}$ & $81.33^{b}$ & 70.17 \\
\hline & Syrup & $178.33^{\mathrm{a}}$ & $168.33^{\mathrm{ab}}$ & $152.00^{\mathrm{b}}$ & $128.33^{b}$ & $107.67^{b}$ & 57.25 \\
\hline & Candy & $180.67^{\mathrm{a}}$ & $155.67^{\mathrm{ab}}$ & $136.33^{\mathrm{bc}}$ & $110.0^{\mathrm{b}}$ & $87.67^{\mathrm{b}}$ & 62.34 \\
\hline & Mean & $\mathbf{1 7 7 . 6 7}$ & 162.49 & 144.44 & $\mathbf{1 2 1 . 1 3}$ & 92.44 & 62.74 \\
\hline \multirow{3}{*}{ Rifampicin } & $\begin{array}{l}\text { Powdered } \\
\text { sugar }\end{array}$ & $170.0^{\mathrm{a}}$ & $137.0^{\mathrm{ab}}$ & $76.67^{\mathrm{d}}$ & $33.33^{\mathrm{d}}$ & $10.00^{\mathrm{c}}$ & 96.24 \\
\hline & Syrup & $174.0^{\mathrm{a}}$ & $157.33^{\mathrm{ab}}$ & $112.3^{\text {bcd }}$ & $76.33^{c}$ & $37.00^{c}$ & 84.94 \\
\hline & candy & $177.00^{\mathrm{a}}$ & $141.67^{\mathrm{ab}}$ & $102.67^{\mathrm{cd}}$ & $63.67^{\mathrm{c}}$ & $22.33^{\mathrm{c}}$ & 90.21 \\
\hline & Mean & 173.66 & 145.33 & 97.22 & 57.77 & 23.11 & 90.47 \\
\hline \multirow{4}{*}{ Control } & $\begin{array}{l}\text { Powdered } \\
\text { sugar }\end{array}$ & $167.33^{\mathrm{a}}$ & $179.00^{\mathrm{a}}$ & $206.33^{a}$ & $227.67^{\mathrm{a}}$ & $262.33^{\mathrm{a}}$ & \\
\hline & Syrup & $171.00^{\mathrm{a}}$ & $187.67^{\mathrm{a}}$ & $204 . .67 \mathrm{a}$ & $227.33^{\mathrm{a}}$ & $241.33^{\mathrm{a}}$ & \\
\hline & candy & $178.67^{\mathrm{a}}$ & $185.67^{\mathrm{a}}$ & $200.67^{\mathrm{a}}$ & $214.0^{\mathrm{a}}$ & $230.26^{\mathrm{a}}$ & \\
\hline & Mean & 172.33 & 181.78 & 201.43 & 220.05 & 240.70 & \\
\hline \multicolumn{2}{|c|}{ P value (antibiotics) } & $0.4363 \mathrm{~ns}$ & $0.0679 \mathrm{~ns}$ & $0.00 * * *$ & $0.00 * * *$ & $0.0000 * * *$ & \\
\hline \multicolumn{2}{|c|}{ P value ( APP. methods ) } & $0.3757 \mathrm{~ns}$ & $0.3004 \mathrm{~ns}$ & $0.0585^{* * *}$ & $0.0325 * *$ & 0.0607 & \\
\hline \multicolumn{2}{|c|}{$P$ value $(A \times M)$} & $0.9631 \mathrm{~ns}$ & $0.9515 \mathrm{~ns}$ & $0.5060 \mathrm{~ns}$ & $0.1939 \mathrm{~ns}$ & $0.5182 \mathrm{~ns}$ & \\
\hline \multicolumn{2}{|l|}{ LSD 5\% } & & 51.690 & 40.698 & 25.302 & 29.735 & \\
\hline
\end{tabular}

R\%*: percentage of reduction in no. of infected cells post the fourth treatments. ns: Not significant, $* *$ : Significant at 0.01 level of probability, ***: Significant at 0.001 level of probability 


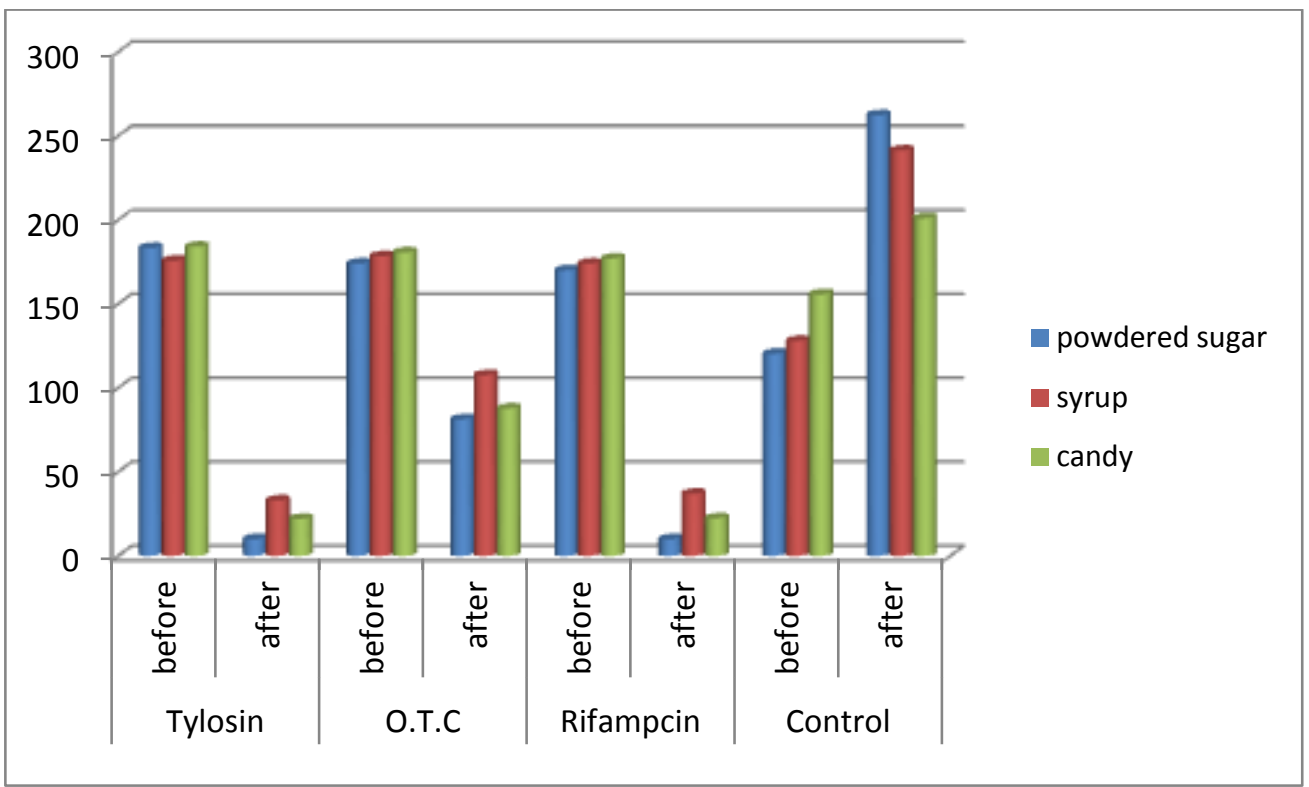

Figure (1). The effect of using three antibiotics and three application methods on the means number of infected before and after treatment

Moreover, the method of application of the three antibiotics has clear effect on the efficiency. For instance mixing the three antibiotics in powdered sugar to be sprinkled on the top bars of brood combs proved to be the most potent method of application, meanwhile dissolving the antibiotics in sucrose syrup was the least potent method of application.

\section{2- The rate of reduction of $A F B$ infection:}

AS shown in Table 1, the rate of reduction in the percentage of AFB infection recorded $91.43,62.74$ and $90.47 \%$ for tylosin , oxytetracycline and rifampicin , respectively, regardless of the method of application.

Regarding the method of application of the test antibiotics, data revealed that applying the antibiotics in powdered sugar caused the highest reduction percentage, recording $96.49,70.17$ and $96.24 \%$ for tylosin, oxytetracycline and rifampicin, respectively . Candy method of application came in the second class ,recording 90.72, 62.74 and $90.21 \%$ for tylosin, oxytetracycline and rifampicin, respectively whereas syrup method approved to be the least potent method recording $86.70,57.25$ and $84.94 \%$ for tylosin , oxytetracycline and rifampicin, respectively.The differences between the test antibiotics and the control were 
mostly significant . The same trend was also recorded between the methods of application.

It could be concluded that tylosin proved to be the most effective antibiotic used to control American foulbrood disease, especially when used mixed in powdered sugar methods. This result is in agreement with that of Alippi et al.,(1999) and Pettis and Feldlaufer (2005) as well as field assays carried out by Kamel et al. (2013) who reported that the treatment of beehives affected with AFB disease by Tylosin 1\% eliminated clinical symptoms, recording $100 \%$ reduction rate. Also Sanad and Al-Barrak (2010) referred to that tylosin gave $97.7 \%$ reduction of the AFB disease compared with clove or watercress oils which resulted in 89 to $95.2 \%$ reduction. Meanwhile, Reynaldi et al .2017) indicated that there was no statistical difference between the treatments (dusting or paper-pack).In addition, rifampicin came in the second class, giving satisfactory results in the three methods to be in accordance with the findings of Kochansky et al (2001) who demonstrated that the rifampicin antibiotic proved to be the most effective antibiotic among the tested twenty seven with MIC of $1.8 \mathrm{mg} / \mathrm{l}$. Also, Gurgulova et al (2003) detected that the rates of the minimum lowering concentrations have their lowest values with rifampicin, manifesting good perspectives for treatment of bee bacterial diseases. Moreover, Goda (2011) reported that the P. L. Larvae showed sensitivity to six of tested antibiotics and the highest activity was for rifampicin which inhabited the growth with inhibition zone diameter $(44 \mathrm{~mm})$.

The lowest efficiency of oxytetracycline against Paenibacillus larvae could be attributed to the elevated resistance of $P$. larvae to this antibiotic . Similar trend are also reported by Murray and Aronstein (2006) and Cougoule et al. (2008). In addition, Krongdang (2017) reported that P. L. Larvae isolates were screened for resistance to four antibiotics used by U.S. beekeepers, showing extensive resistance to tetracycline. Therefore ,It is preferable to alternate the use of different antibiotics in order to prevent the development of drug resistance.

Conclusively, Tylosin was the most effective antibiotic used in controlling American foulbrood disease when it used in the powdered sugar methods in decreasing the number of infected cells where the average number of infected cell decreased from183.33 before treatment to 10.00 after the $4^{\text {th }}$ treatment and in the reduction percentage, where its reduction percentage was $96.47 \%$. 


\section{REFERENCES}

Alippi, A.M. (1999). Bacterial diseases. CIHEAM- IAMZ, Options Méditerranéennes: Série B. Etudes et Recherches, 2 5:31-59.

Alippi, A. M.; Lopez, A. C. and Aguilar, O. M. (2002): Differentiation of Paenibacillus larvae subsp. larvae, the cause of American foulbrood of honeybees, by using PCR and Restriction Fragment Analysis of genes encoding 16s r-RNA. J. Appl. Environ. Microbiol., 68: 3655-3660.

Alippi, A.M.; Lopez, A.C.; Reynaldi, F.J.; Grasso, D.H. and Aguilar, O.M. (2007). Evidence for plasmid-mediated tetracycline resistance in Paenibacillus larvae, the causal agent of American Foulbrood (AFB) disease in honeybees. J. Vet. Microbiol., 125(3/4):290-303.

Bastos, E.M.A.F.; Simone, M.; Jorge, D.M.; Soares, A.E.E. and Spivak, M. (2008). In vitro study of the antimicrobial activity of Brazilian propolis against Paenibacillus larvae. J. of Inverteb. Path. , 97(3):273-281.

Chen, Y.W.; Liu, J.S.; Ho, K.K.; Wang, C.H. and An, J. (2001). Control effects of oxytetracycline on American foulbrood, Paenibacillus larvae larvae, of honey bee, Apis mellifera. Formosan Entomologist;. 21(3):209220.

Cougoule, N.; Abadie, G.; Vautor, E.; Chauzat, M.P.; Aubert, M. and Faucon, J.P. (2008). Study of the sensitivity to tetracycline of European isolates of Paenibacillus larvae, the causal agent of American foulbrood in honey bees (Apis mellifera). Revue de Medecine Veterinaire; 159(6):323326. 19 ref.

Elzen, P.J.; Westervelt, D. Causey, D.; Ellis, J.; Hepburn, H.R. and Neumann, P. (2002). Method of Application of Tylosin, an Antibiotic for American Foulbrood Control, with Effects on Small Hive Beetle (Coleoptera: Nitidulidae) Populations; J. Econ. Entomol. 95(6): 11191122.

Evans, J.D. and Pettis, J. S. (2005). Colony-level impacts of immune responsiveness in honey bees, Apis mellifera. Evolution 59: 2270-2274.

Forsgren, E.; Locke, B.; Sircoulomb; F.; Oliver, M. and Clin, S. (2018). Bacterial Diseases in Honeybees .Microbiology. Reports ,5:18-25.

Genersch, E.; Ashiralieva, A. and Fries, I. (2005). Strain- and genotypespecific differences in virulence of Paenibacillus larvae subsp. larvae, the causative agent of American foulbrood disease in honey bees. Applied Environmental Microbiology, 71: 7551-7555. 
Goda, Hend, I. A. (2011). Studies on microbial diseases of honeybee (Apis mellifera) colonies .M. Sc. Thesis, in Microbiology, Bot. Dep., Fac. science, Benha Univ., 145 pp.

Gurgulova, k. Panchev, I. and Stanchev, P., (2003). A study on antibacterial activity of riphampizyn against bee disease microorganisms. J. Uludag Bee, PP.40-41.

Heisey, D. and Nimis, G. (1985). Statistix: an interactive statistical program for microcomputers. NIH Ana lytical Software, St. Paul, MN.

Henderson, C.F. and Tilton, E. W. (1955). Tests with acaricides against the brown wheat mite. J. Econ. Entomol., 48:157-161.

Kamel, A.A.; Moustafa, A.A. and Nafea, E.A. (2013). Propolis as a natural antibiotic to control American foulbrood disease in honey bee colonies. Afr. J. Agric. Res., 8(23):3047-3062.

Kochansky. J.; Knox, D.; Feldlaufer, M. and Pettis, J. (2001). Screening alternative antibiotics against oxytetracycline-susceptible and -resistant Paenibacillus larvae. Apidologie, 32 (3): 215-222.

Krongdang, S.; Evans, J.D.; Pettis, J.S.; Chantawannakul, P. (2017). Multilocus sequence typing, biochemical and antibiotic resistance characterizations reveal diversity of North American strains of the honey bee pathogen Paenibacillus larvae. J. Plos One; 12(5):e0176831.

Morse, R.A. and Shimanuki, H. (1990). Summary of control methods. In Honey Bee Pests, Predators and Diseases. 2nd edn, Morse, R.A and Nowogrodzki, R. (eds). Cornell University Press, USA., pp. 341 -36.

Murray, K.D.; Aronstein, K.A. (2006). Oxytetracycline-resistance in the honey bee pathogen Paenibacillus larvae is encoded on novel plasmid pMA67. Journal of Apicultural Research, 45(4):207-214.

Mutinelli, F. (2003). Practical Application of antibacterial drugs for the control of honey bee diseases, APIACTA, 38: 149-155.

OIE (2013). Manual of Diagnostic Tests and Vaccines for Terrestrial Animals. Paris, France: World Organisation for Animal Health .http://www.oie. int/ en/international- standard-setting/terrestrial-manual/access-online/

Peng, C. Y.; Mussen, E.; Fong, A.; Cheng, P.; Wong, G. and Montague, M. A. (1996). Laboratory and field studies on the effects of the antibiotic tylosin on honey bee Apis mellifera L. (Hymenoptera: Apidae) development and prevention of American foulbrood disease. Journal Inverteb.Path., 67, 65-71. 
Pettis, J. S. and Feldlaufer, M. F. (2005). Efficacy of lincomycin and tylosin in controlling American foulbrood in honey bee colonies; Journal of Apicult. Res., 44(3):106-108.

Sanad, R.E. and Al-Barrak, A. S. (2010). Use of clove and watercress oils for controlling the American Foulbrood disease attacking honeybee colonies at El-Gharbia Governorate, Egypt. Egyptian J. Biol. Pest Cont., 20(1):33-36.

Reynaldi, F.J.; Albo, G.N.; Giusti, M.; Alippi, A.M. (2009). Determination of the optimum doses of tylosin tartrate for the control of American foulbrood in honey bee colonies. Analecta Veterinaria;. 29(2):24-30.

Reynaldi, F.J.; Albo, G.; Avellaneda, E. and Rule, R. (2017). Evaluation of kinetic behaviour of two preparations of tylosin administered in beehives for American foulbrood control. Bulg. J. Vet. Med., 20 (3): 264-270.

Ryba, S.; Kindlmann, P.; Titera, D.; Haklova, M. and Stopka, P. (2012). A new low cost procedure for detecting nucleic acids in low-incidence samples: a case study of detecting spores Paenibacillus larvae from bee debris. Journal of Economic Entomology, 105(5): 1487-1491.

Yue, D.; Nordhoff, M.; Wieler, L.H. and Genersch, E. (2008). Fluorescence in situ hybridization (FISH) analysis of the interactions between honeybee larvae and Paenibacillus larvae, the causative agent of American foulbrood of honeybees (Apis mellifera). Environ. Microbiol., 10(6):1612-20. 


\section{كفاءة بعض المضادات الحيوية المستخدمة لمكافحة مرض تعفن الأن المعل

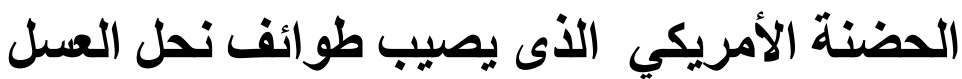

1 مصطقى عبدالباسط1 ، فتحي السنطيل2، حزة محمد الشرقاوي²، أحمد محمود خطابي

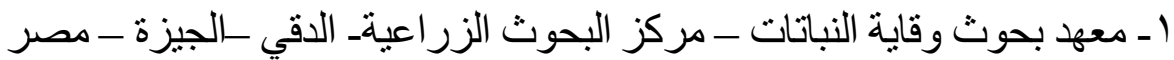

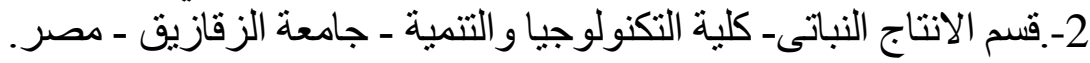

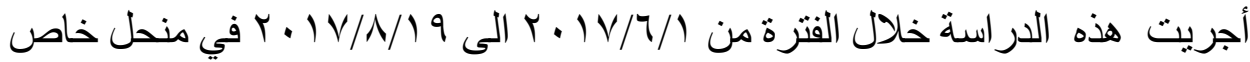

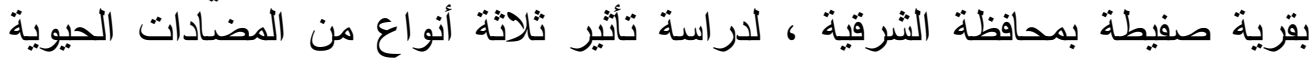

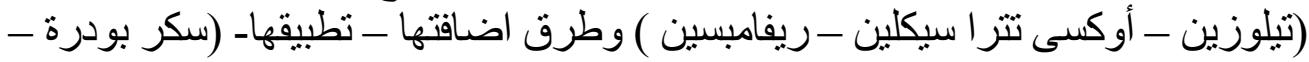
كاندي - محلول سكرى) على التغير فى تعداد العيون المصابة بمرض اضفين عفن الطضنة تم اعداد بـ طائفة متساوية فى القوة بحيث بكون في كل طائفة ب أقر اص حضنة

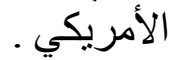

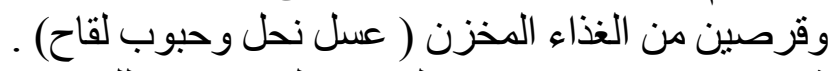

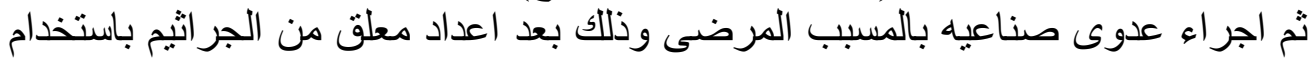

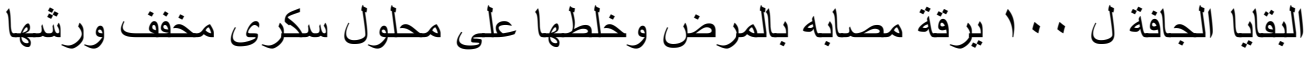

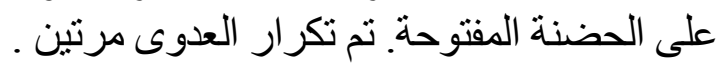

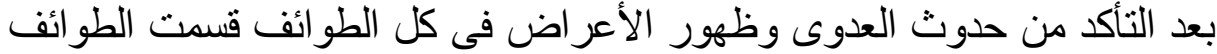

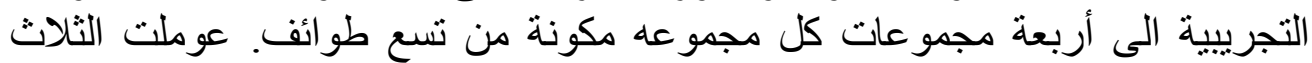

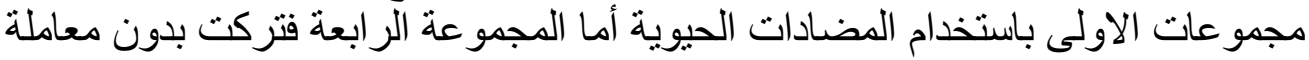

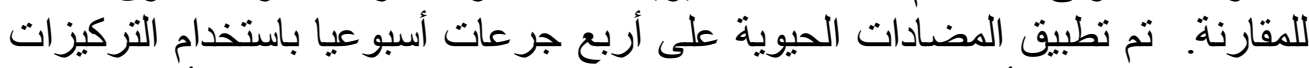

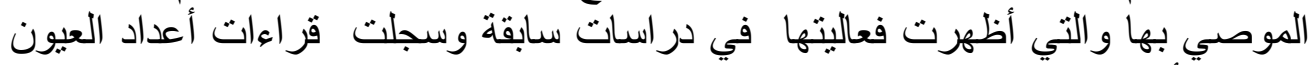
المصابة أسبو عيا بانتظام.

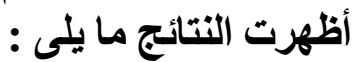
أولا: طرق المعاملة بالمضادات الحيوية:

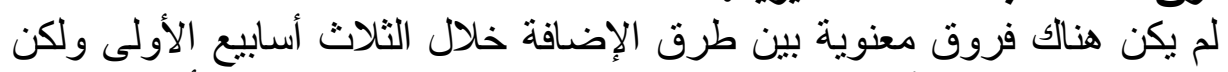

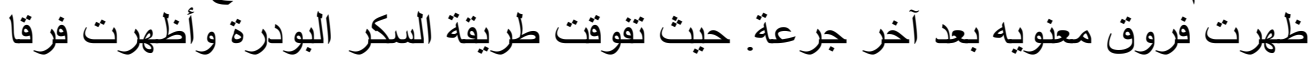

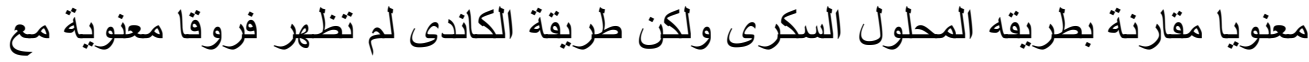


ثانيا / كفاوة المضادات الحيوية:

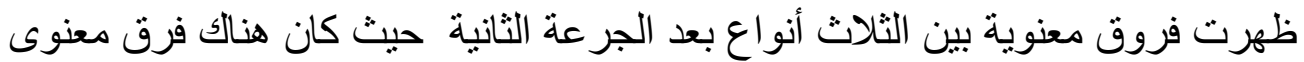

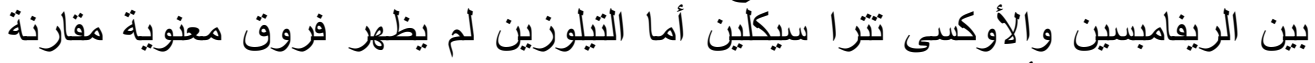

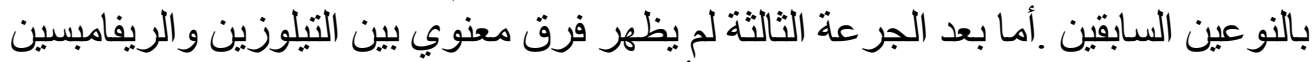

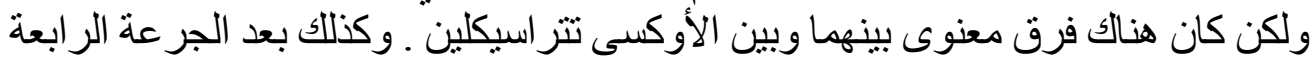

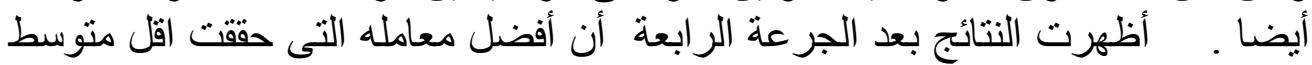

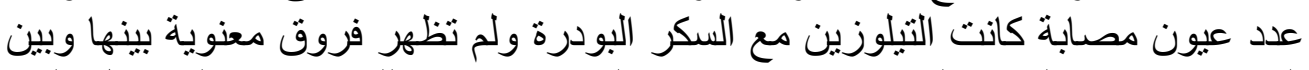

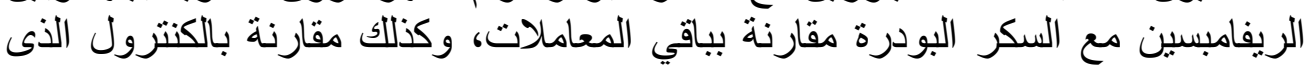

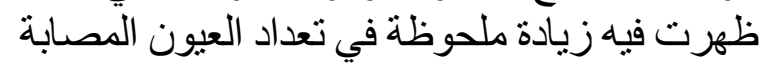
ثالثا / معدل الخفض في في نسبة الاصنية

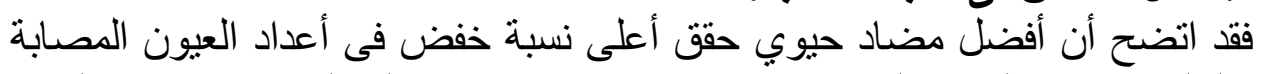

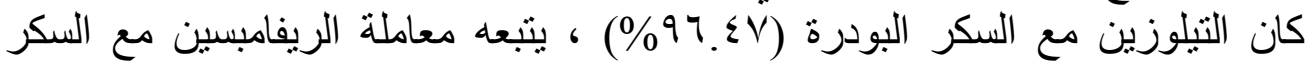

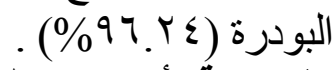

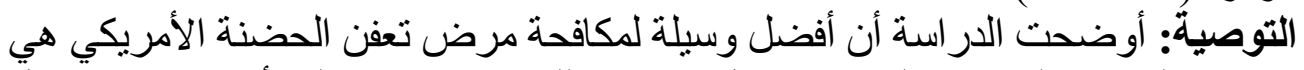

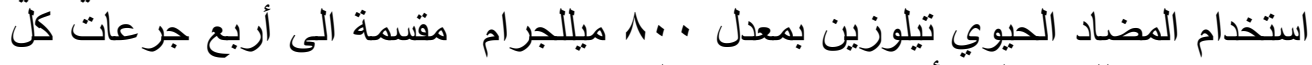

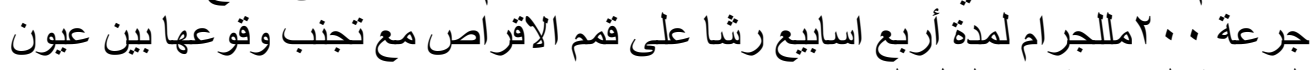

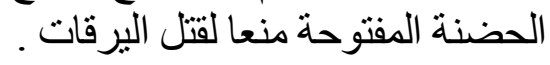

